\title{
PERILAKU DINAMIK PELAT PERKERASAN KAKU JALAN RAYA AKIBAT BEBAN LEDAKAN SETEMPAT
}

\author{
Anjas Budi Priono ${ }^{1}$, Sofia Wangsadinata Alisjahbana ${ }^{2}$ \\ ${ }^{1}$ Magister Teknik Sipil, Universitas Tarumanagara Jakarta \\ Email:anjas_26@yahoo.com \\ ${ }^{2}$ Magister Teknik Sipil, Universitas Tarumanagara Jakarta \\ Email: sofia.wangsadinata@gmail.com
}

\begin{abstract}
ABSTRAK
Dalam aplikasi rekayasa struktur dan teknik transportasi, respons dinamik pelat ortotropik adalah masalah penting. Pelat perkerasan kaku jalan raya umumnya didesain sebagai pelat ortotropik yang memiliki kekakuan yang tidak sama dalam dua arah yang saling tegak lurus. Pelat perkerasan kaku jalan raya sering kali didesain oleh para insinyur tidak memperhitungkan efek dari beban dinamik lain seperti beban yang berasal dari getaran mesin atau ledakan. Analisis dinamik pelat perkerasan kaku jalan raya akibat beban ledakan setempat di atas pelat beton dalam tesis ini dimodelkan sebagai pelat beton dengan kondisi semua tepi pelat beton memiliki tumpuan dowel - tie bar dan di atas media tanah dengan model pondasi Pasternak dari teori Kirchoff-Love mengenai pelat tipis. Pondasi Pasternak memiliki dukungan pegas vertikal elastis dan lapisan geser menerus di bawahnya. Respons sistem yang diamati adalah lendutan transversal pada tengah bentang dan tegangan dalam pada pelat, khususnya tegangan utama maksimum, tegangan utama minimum dan tegangan geser maksimum. Tiga tahap beban disertakan dalam analisis, yaitu fase positif, fase negatif dan fase getaran bebas. Analisis dikerjakan dengan pendekatan numerik yang disebut Modified Bolotin Method dengan bantuan dua persamaan transendental. Analisis dilakukan ketika beban berada di atas pelat $\left(0 \leq \mathrm{t} \leq \mathrm{t}_{0}\right)$. Lendutan dari beberapa posisi beban dari tiga tahap dibandingkan. Momen lentur, gaya geser, dan tegangan dihitungkan pada semua model dengan letak beban setempat Friedlander di tengah bentang. Nilai tegangan disajikan dalam bentuk grafik kontur yang dapat dibandingkan antara setiap model. Hasil penelitian menunjukkan respons dinamik struktur terbesar terjadi pada fase free vibration, bukan pada fase positif maupun fase negatif. Pengurangan lendutan dan momen lentur apabila ditinjau berdasarkan pengaruh paling singnifikan, ketebalan pelat adalah urutan pertama diikuti pengaruh posisi ledakan apabila terjadi makin ke tepi pelat, dan terakhir penambahan kekakuan lapisan tanah pendukung.
\end{abstract}

Kata Kunci: beban ledakan setempat; dowel dan tie bar; modified bolotin method; perkerasan kaku; pondasi pasternak

\section{ABSTRACT}

In structural and transportation engineering applications, the dynamic response of orthotropic plates is an essential matter. Rigid pavement plates are generally designed as orthotropic plates which have unequal stiffness in two perpendicular directions Engineers did not consider the effects of dynamic loads such as those from machine vibrations or blast load. Dynamic analysis of rigid pavement plates due to local blast loads on concrete slabs in this research is modeled as concrete slabs with boundary condition that every edges of plates have a dowel-tie bar support and The rigid concrete pavement sitting on elastics Pasternak foundation is modeled by using the Kirchhoff theory of thin plates. Pasternak foundation have elastic vertical spring support and continuous shear layer. The main system responses that are observed are the transversal deflections at midspan and the internal stresses of the plate, particularly the maximum principle stress, minimum principle stress and maximum shear stress. Three loading phases are included in the analysis, namely: the positive phase, the negative phase, and the free vibration phase. Analyses are carried out utilizing a numeric approach termed the Modified Bolotin Method with two trancedental equation. The analysis is performed when the load is above the plate $(0 \leq t \leq t 0)$. Deflection from various load positions on the set of slab models throughout all three phases are then compared side-by-side. Bending moment, shear forces, and stresses are calculated on all slab models with the Friedlander localized blast loading applied at midspan and the results are presented as stress contours that are then compared between each model. The results showed that the largest structural dynamic response occurred in the free vibration phase, not in the positive phase or the negative phase. Reduction of deflection and bending moment based on the most significant effect, plate thickness is the first followed by the effect of explosion position if it occurs further to edge of plate, and latest is adding supporting stiffness soil layer.

Keywords: dowel and tie-bar; Localized blast load; Modified Bolotin Method; Pasternak foundation; Rigid Pavement 


\section{PENDAHULUAN}

\section{Latar Belakang}

Sedekade terakhir perhatian mengenai perilaku struktur bangunan telah meningkat. Penggunaan bahan peledak pada struktur karena peristiwa kebetulan atau kesengajaan telah menjadi subyek dari penelitian dalam beberapa tahun. Dari serangkaian kejadian teror ledakan bom dari tahun 2000 sampai dengan 2019. Pada tahun 2004 terjadi ledakkan di depan Gedung kedutaan besar Australia dengan menggunakan bom mobil. Akibat dari ledakkan tersebut terjadi kerusakan pada beberapa fasilitas publik baik gedung maupun perkerasan jalan raya. Untuk memberikan perlindungan yang memadai terhadap ledakan, desain pelat beton di atas tanah, dan infrastruktur perkerasan jalan kepada publik dibutuhkan penelitian lebih mendalam mengenai akibat dari beban ledakan.

Struktur pelat yang sering digunakan pada jalan adalah struktur perkerasan kaku (lapis beton) dan struktur perkerasan lentur (lapis aspal). Perkerasan kaku dinilai memberikan beberapa kelebihan salah satunya dapat digunakan pada kondisi tanah dasar yang mempunyai daya dukung rendah maupun tidak seragam.

Jenis pelat menurut sifat mekanis bahan terbagi menjadi tiga antara lain pelat isotropik, pelat ortotropik, dan pelat anisotropik. Pelat isotropik merupakan pelat dengan sifat elastis mekanis bahan yang sama di semua arahnya, sementara pelat ortotropik merupakan pelat dengan sifat mekanis bahan yang tidak sama untuk kedua arah sumbu saling tegak lurus, dan pelat anistropik memiliki sifat mekanis bahan yang berbeda di semua arah. Adapun pelat perkerasan kaku jalan raya termasuk salah satu contoh jenis pelat ortotropik yang berfungsi sebagai elemen penahan beban lateral maupun vertikal.

Suatu permasalahan yang sering kali dihadapi pada pelat perkerasan jalan raya adalah para insinyur sering tidak memperhitungkan efek dari beban dinamik lain seperti beban yang berasal dari getaran mesin atau ledakan. Beban ledakan termasuk beban dinamik yang membebani struktur di luar kondisi biasa. Beberapa peneliti telah melakukan penelitian terhadap sebuah pelat orthotropik persegi panjang. Khadid et. al (2007) meneliti efek dari beban ledakan pada pelat lantai dengan perletakan kaku sempurna untuk mengetahui respon dari pelat dengan variasi konfigurasi pengaku pelat. Kerr (1964) memperkenalkan model pondasi elastis yang paling sederhana dimana lapisan tanah pendukung dimodelkan sebagai lapisan pegas pendukung yang tersebar merata di sepanjang pelat. Tetapi model ini hanya berlaku untuk beban yang seragam dikarenakan tidak ada perhitungan koneksi antar lapisan tanah sehingga menghasilkan bentuk deformasi yang seragam di sepanjang pelat (Alisjahbana S, 2015).

Jenis penyelesaian untuk permasalahan respons dinamik pelat perkerasan ada beberapa jenis. Metode yang cukup sering digunakan karena dapat menyelesaikan permasalahan pelat baik frekuensi alami dan getaran bebas adalah Bolotin Method. Metode ini digunakan untuk menyelesaikan masalah pelat secara numerik dengan menggunakan fungsi trigonometri (Pevzner et. al, 2000). Dalam penelitian Vijakumar pada tahun 1971 yang berjudul "A New Method for Analysis of Flexural Vibration of Rectangular Orthotropic Plates" memodifikasi metode Bolotin dengan menambahkan suku yang diabaikan oleh Bolotin sebelumnya dan memberikan hasil yang lebih akurat dengan kondisi perletakan yang beragam terutama untuk ragam getar yang lebih tinggi.

Dimensi pelat beton yang digunakan untuk analisis sesuai dengan dimensi pelat beton standar yang digunakan oleh PT Jasa Marga untuk pembangunan perkerasan kaku jalan raya dan pada pertemuan bagian tepi pelat yang satu dengan yang lain dalam arah $\mathrm{x}$ dan sumbu y biasanya 
digunakan alih beban (load transfer device) berupa dowel maupun berupa batang pengikat (tie bar). Dukungan pada bagian tepi pelat yang dapat dikerahkan oleh dowel atau batang pengikat sepanjang tepi pelat yang disambung adalah berupa dukungan vertikal akibat adanya kekakuan terhadap lendutan dalam arah vertikal dan kekakuan tahanan rotasi akibat adanya kekakuan menahan momen dari dowel yang terpasang sepanjang tepi pelat tersebut (Alisjahbana S, 2015).

Struktur pelat dalam penelitian ini menggunakan beton yang memiliki sifat ortotropik, yaitu memiliki kekakuan yang berbeda antara sumbu x dengan sumbu $\mathrm{y}$. Asumsi yang digunakan untuk perletakan pelat pada keempat sisi pelat perkerasan kaku pada penelitian ini adalah perletakan dowel - tie bar sehingga metode Modified Bolotin Method digunakan sebagai penyelesaian respons dinamik pelat perkerasan.

Tujuan dari penelitian ini adalah untuk mengetahui pengaruh variasi posisi beban ledakan, pengaruh variasi kekakuan pada pelat, dan pengaruh variasi ketebalan pada pelat terhadap respons dinamik pelat perkerasan kaku jalan raya.

\section{METODE PENELITIAN}

Penelitian dengan melakukan analisis numerik pada perangkat lunak Wolfram Mathematica 11.0 dengan mengumpulkan data di lapangan tanpa uji eksperimental di laboratorium.

Alur penelitian ditampilkan dalam bagan alir kerja (flow chart) pada Gambar 1 sebagai berikut:

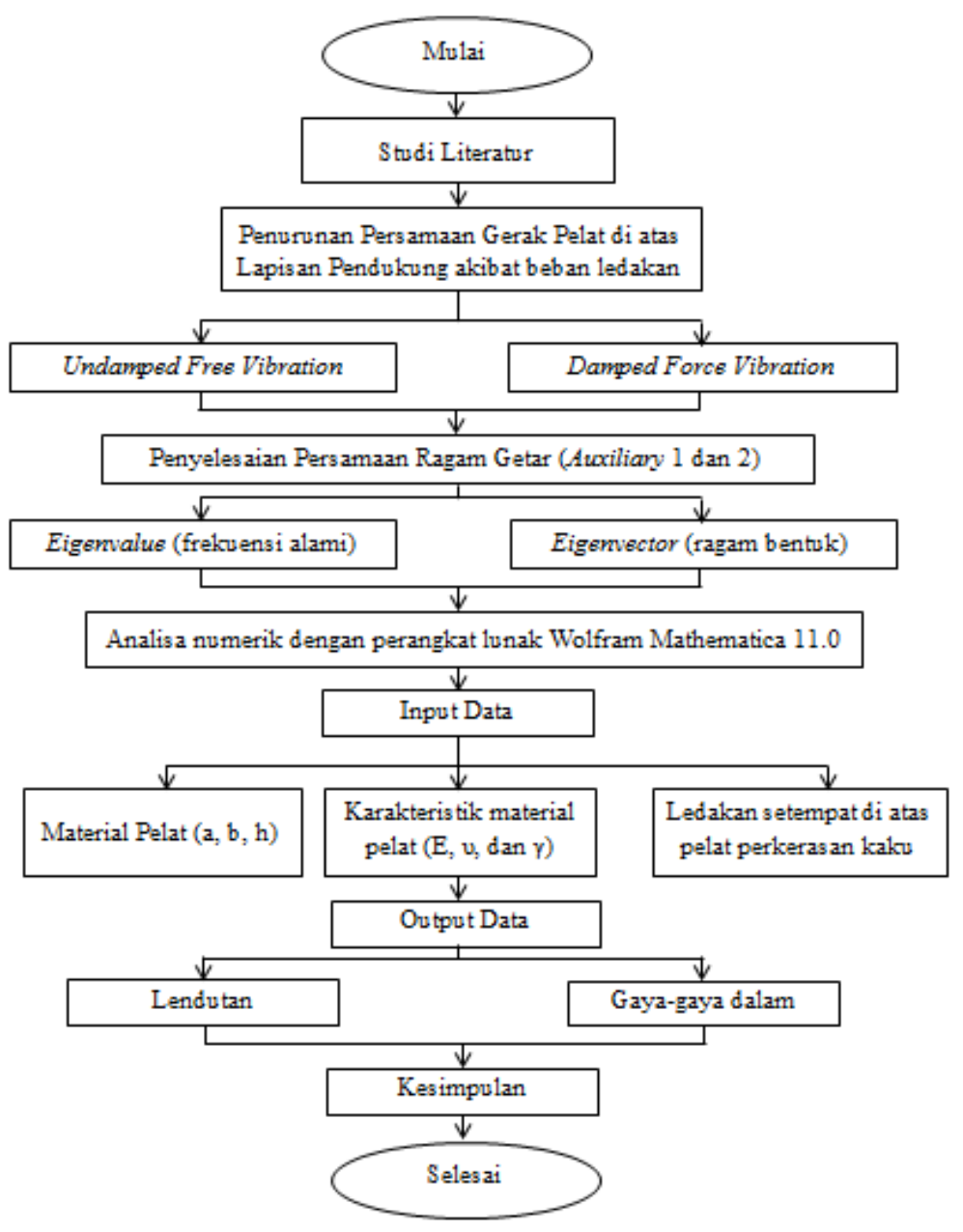

Gambar 1. Alur Penelitian 
Metodologi penelitian pada penelitian adalah dengan cara:

a. Pemasukan parameter geometri dan material pelat lantai, serta beban yang bekerja ke dalam perangkat lunak Wolfram Mathematica 11.0.

b. Penyelesaian masalah-masalah auxiliary untuk memperoleh wave number ( $p$ dan $q$ ) dan pola ragam getar dari pelat.

c. Analisis terhadap lendutan dan tegangan yang ditimbulkan oleh beban setempat Friedlander yang bekerja pada beberapa posisi di dalam pelat perkerasan kaku.

\section{HASIL DAN PEMBAHASAN}

Analisis dalam penelitian ini untuk mendapatkan nilai-nilai gaya dalam dan lendutan. Nilai gayagaya dalam meliputi momen dan geser. Pelat perkerasan kaku yang diteliti dimodelkan sebagai pelat yang bersiat elastis, homogen, dan ortotropik. Dimensi pelat beton yang digunakan untuk analisis sesuai dengan dimensi pelat beton standar yang digunakan PT Jasa Marga untuk pembangunan perkerasan kaku jalan raya. Pada pertemuan bagian tepi pelat yang satu dengan yang lain dalam arah sumbu $x$ dan sumbu $y$ digunakan alat alih beban (load transfer device) berupa dowel-tie bars. Modul pelat mempunyai dimensi 3500 x $5000 \mathrm{~mm}$ dengan tumpuan di keempat sisinya berupa dowel dan tie bars. Respons dinamik struktur yang dihitung adalah lendutan dan tegangan utama pada seluruh daerah pelat.

Besaran respons tersebut dihitung pada beberapa bagian atau fase yang berbeda, berdasarkan fungsi dari beban yang digunakan. Analisis untuk tiap fase ini memerlukan rumusan yang berbeda sehingga perlu dianalisis secara terpisah atau individu. Adapun fase-fase tersebut adalah sebagai berikut:

a. Fase positif, waktu ketika amplitudo beban ledakan adalah positif, sehingga dianggap memberi tekanan positif terhadap pelat (menuju pelat). Pada fase ini, initial condition adalah nol dan sehingga respons struktur hanya dari beban yang bekerja. Solusi yang digunakan adalah solusi partikuler dari penyelesaian persamaan diferensial.

b. Fase nol, waktu ketika amplitudo beban ledakan adalah nol, sehingga pelat hanya mengalami free vibration dengan initial condition pada akhir fase positif. Respons struktur hanya dihitung menggunakan solusi homogen pada fase ini.

c. Fase negatif, waktu ketika amplitudo beban ledakan adalah negatif, sehingga dianggap memberi tekanan negatif terhadap pelat (menjauhi pelat). Pada fase ini, terdapat initial condition dari respons akhir fase positif dan juga beban hisap dari ledakan. Oleh karena itu diperlukan solusi total dari persamaan diferensial, yaitu penjumlahan dari solusi homogen dan solusi partikuler

d. Fase getaran bebas, waktu saat beban sudah tidak bekerja lagi dan struktur hanya bergetar harmonis dari initial conditions dari respons akhir fase negatif. Respons struktur hanya dihitung menggunakan solusi homogen pada fase ini.

\section{Parameter Objek Penelitian}

Penelitian mempunyai berbagai nilai properti yang disajikan dalam Tabel 1 berikut:

Tabel 1. Material Properties Pelat Lantai

\begin{tabular}{lccc}
\hline Deskripsi & Notasi & Nilai & Satuan \\
\hline Panjang pelat (sejajar sumbu x) & $\mathrm{a}$ & 5 & $\mathrm{~m}$ \\
\hline Lebar pelat (sejajar sumbu y) & $\mathrm{b}$ & 3,5 & $\mathrm{~m}$ \\
\hline Tebal pelat & $\mathrm{h}$ & $0,23 \sim 0,25$ & $\mathrm{~m}$ \\
\hline Massa jenis beton & $\rho$ & 2400 & $\mathrm{~N} / \mathrm{m}^{3}$ \\
\hline
\end{tabular}




\begin{tabular}{lccc} 
Modulus elastisitas beton arah sumbu x & $\mathrm{E}_{\mathrm{x}}$ & $27,8 \times 10^{9}$ & $\mathrm{~N} / \mathrm{m}^{2}$ \\
\hline Modulus elastisitas beton arah sumbu y & $\mathrm{E}_{\mathrm{y}}$ & $30,0 \times 10^{9}$ & $\mathrm{~N} / \mathrm{m}^{2}$ \\
\hline Kekakuan rotasi dalam arah x & $\mathrm{k}_{\mathrm{rx}}$ & $1 \times 10^{6}$ & $\mathrm{Nm} / \mathrm{rad}$ \\
\hline Kekakuan rotasi dalam arah y & $\mathrm{k}_{\mathrm{ry}}$ & $1 \times 10^{6}$ & $\mathrm{Nm} / \mathrm{rad}$ \\
\hline Kekakuan translasi vertikal dalam arah x & $\mathrm{k}_{\mathrm{sx}}$ & $2,0 \times 10^{8}$ & $\mathrm{~N} / \mathrm{m}$ \\
\hline Kekakuan translasi vertikal dalam arah y & $\mathrm{k}_{\mathrm{sy}}$ & $2,0 \times 10^{8}$ & $\mathrm{~N} / \mathrm{m}$ \\
\hline Koefisien Redaman & $\gamma$ & 0,05 & \\
\hline
\end{tabular}

\section{Variasi Studi Kasus Penelitian}

Kasus 1A sampai dengan kasus 5D berturut-turut mempunyai variasi posisi ledakan, ketebalan pelat, dan kekakuan lapisan tanah pendukung $k$. Adapun 5 kasus besar yang diteliti pada penelitian disajikan dalam Tabel 2 sebagai berikut.

Tabel 2. Variasi Studi Kasus Penelitian

\begin{tabular}{|c|c|c|c|c|c|c|c|c|}
\hline \multicolumn{2}{|c|}{ Kasus } & $\begin{array}{c}\mathrm{a} \\
{[\mathrm{m}]}\end{array}$ & $\begin{array}{c}\mathrm{b} \\
{[\mathrm{m}]}\end{array}$ & $\begin{array}{c}\mathrm{H} \\
{[\mathrm{m}]}\end{array}$ & $\begin{array}{c}\mathrm{x}_{0} \\
{[\mathrm{~m}]}\end{array}$ & $\begin{array}{c}\mathrm{y}_{0} \\
{[\mathrm{~m}]}\end{array}$ & $\begin{array}{c}\mathrm{k} \\
{[\mathrm{MN} / \mathrm{m}]}\end{array}$ & $\begin{array}{c}\text { Gs } \\
{\left[\mathrm{MN} / \mathrm{m}^{2}\right]}\end{array}$ \\
\hline \multirow{4}{*}{1} & $\mathrm{~A}$ & \multirow{4}{*}{5} & \multirow{4}{*}{3.5} & \multirow{4}{*}{0.25} & \multirow{4}{*}{$2.5(4 / 8 * a)$} & \multirow{4}{*}{$1.75(\mathrm{~b} / 2)$} & 27.25 & \multirow{20}{*}{9.52} \\
\hline & $\mathrm{B}$ & & & & & & 54.5 & \\
\hline & $\mathrm{C}$ & & & & & & 81.75 & \\
\hline & $\mathrm{D}$ & & & & & & 109 & \\
\hline \multirow{4}{*}{2} & $\mathrm{~A}$ & \multirow{4}{*}{5} & \multirow{4}{*}{3.5} & \multirow{4}{*}{0.25} & \multirow{4}{*}{$1.875(3 / 8 * a)$} & \multirow{4}{*}{$1.75(b / 2)$} & 27.25 & \\
\hline & $\mathrm{B}$ & & & & & & 54.5 & \\
\hline & $\mathrm{C}$ & & & & & & 81.75 & \\
\hline & $\mathrm{D}$ & & & & & & 109 & \\
\hline \multirow{4}{*}{3} & $\mathrm{~A}$ & \multirow{4}{*}{5} & \multirow{4}{*}{3.5} & \multirow{4}{*}{0.25} & \multirow{4}{*}{$1.25(2 / 8 * a)$} & \multirow{4}{*}{$1.75(\mathrm{~b} / 2)$} & 27.25 & \\
\hline & $\mathrm{B}$ & & & & & & 54.5 & \\
\hline & $\mathrm{C}$ & & & & & & 81.75 & \\
\hline & $\mathrm{D}$ & & & & & & 109 & \\
\hline \multirow{4}{*}{4} & $\mathrm{~A}$ & \multirow{4}{*}{5} & \multirow{4}{*}{3.5} & \multirow{4}{*}{0.25} & \multirow{4}{*}{$0.625(1 / 8 * a)$} & \multirow{4}{*}{$1.75(b / 2)$} & 27.25 & \\
\hline & $\mathrm{B}$ & & & & & & 54.5 & \\
\hline & $\mathrm{C}$ & & & & & & 81.75 & \\
\hline & $\mathrm{D}$ & & & & & & 109 & \\
\hline \multirow{4}{*}{5} & $\mathrm{~A}$ & \multirow{4}{*}{5} & \multirow{4}{*}{3.5} & \multirow{4}{*}{0.23} & \multirow{4}{*}{$2.5(4 / 8 * a)$} & \multirow{4}{*}{$1.75(b / 2)$} & 27.25 & \\
\hline & $\mathrm{B}$ & & & & & & 54.5 & \\
\hline & $\mathrm{C}$ & & & & & & 81.75 & \\
\hline & $\mathrm{D}$ & & & & & & 109 & \\
\hline
\end{tabular}

\section{Riwayat Waktu (Time History) Defleksi Pelat}

Pembebanan dengan beban dinamik berupa beban ledakan setempat dilakukan pada setiap variasi kasus sesuai Tabel 2, sehingga nilai besaran beban dan respons struktur akan berubah terhadap waktu. Defleksi pelat pada tengah bentang dibandingkan terhadap waktu sehingga menghasilkan riwayat waktu lendutan pelat tersebut dalam durasi tertentu. Durasi waktu yang ditampilkan adalah waktu dari 0 detik sampai dengan 0,25 detik supaya semua fase beban bisa ditampilkan secara penuh. Respons struktur untuk masing-masing fase ternyata memiliki nilai yang unik. Untuk fase positif terjadi pada $0<\mathrm{t} \leq 0,0018$ detik, fase negatif terjadi setelah fase positif dimana terjadi pada $0,0018<\mathrm{t} \leq 0,0054$ detik, kemudian fase free vibration terjadi setelah fase negatif dimana terjadi pada $0,0054<\mathrm{t} \leq 0,25$ detik. 


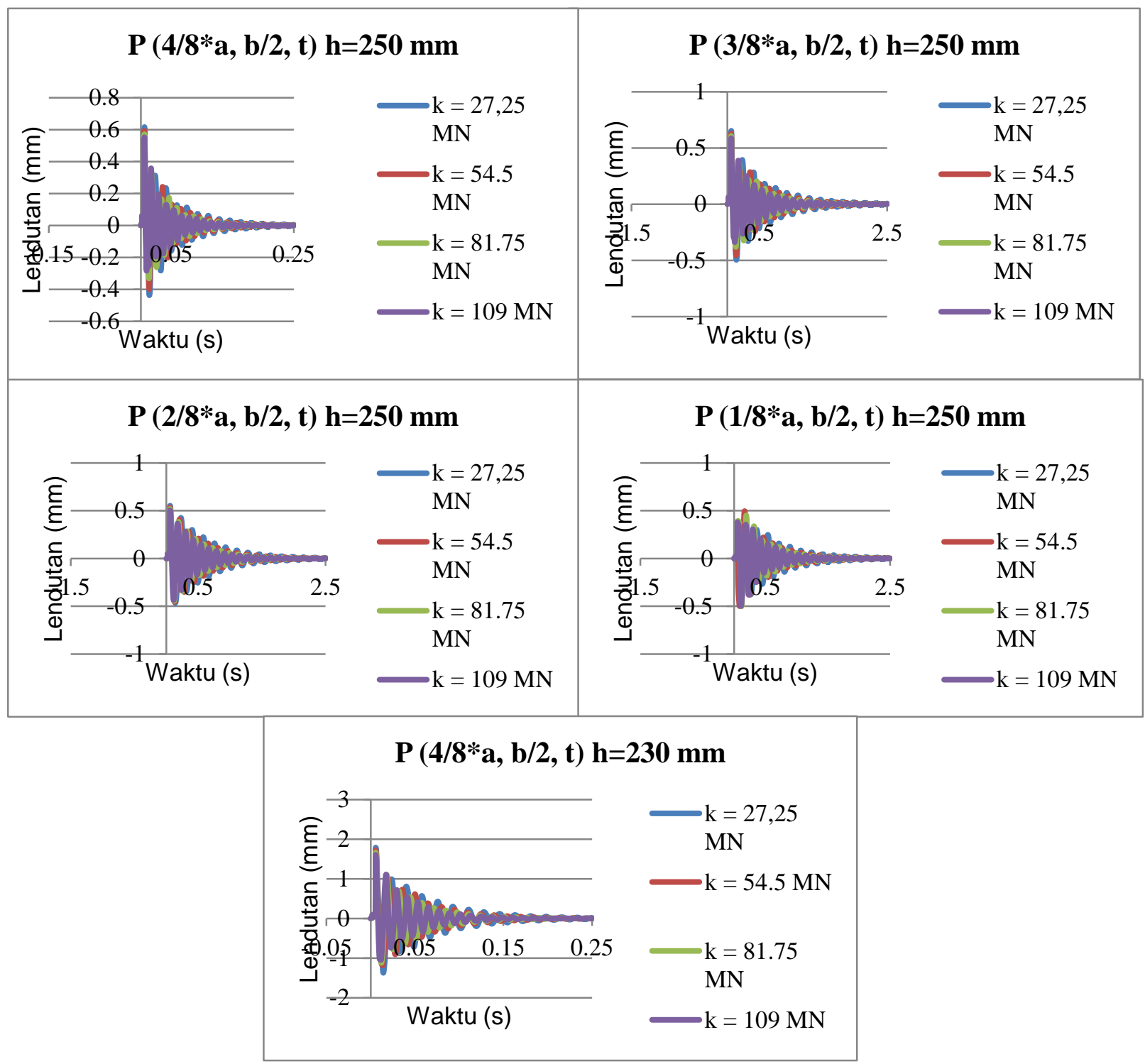

Gambar 2. Time History Lendutan pada Setiap Studi Kasus

Dari Time History lendutan terlihat bahwa setiap model variasi struktur adalah underdamped karena pada fase free vibration amplitudo lendutan berkurang secara bertahap dan akan mencapai lendutan nol setelah beberapa siklus. Hal ini sesuai teori dinamika struktur yang menyatakan struktur dengan rasio redaman kurang dari 1 adalah underdamped.

Gambar 2 menunjukkan bahwa lendutan maksimum terjadi di fase free vibration. Demikian untuk pengaruh ketebalan pelat, semakin berkurang tebal pelat $(h)$ maka lendutan yang terjadi akan semakin besar. Sedangkan pengaruh kekakuan lapisan pendukung $(k)$, apabila nilai $k$ semakin besar maka lendutan yang terjadi semakin kecil.

\section{Lendutan Maksimum Absolut}

Lendutan maksimum absolut adalah defleksi terbesar yang timbul pada pelat selama durasi pembebanan dan setelah beban sudah tidak bekerja lagi (free vibration). Nilai lendutan maksimum absolut bersifat kritis karena ini adalah respons yang paling besar yang mungkin terjadi pada 
struktur, sehingga perlu diperiksa apakah besaran ini tetap memenuhi syarat serviceability dan asumsi-asumsi dalam analisis ditetapkan. Nilai lendutan pada masing-masing studi kasus untuk beban di tengah bentang untuk tebal pelat $250 \mathrm{~mm}$ dan tebal pelat $230 \mathrm{~mm}$ disajikan pada Tabel 3 dan Tabel 4 sebagai berikut:

Tabel 3. Nilai Lendutan dengan beban di tengah bentang untuk tebal pelat $250 \mathrm{~mm}$

\begin{tabular}{cccccccccc}
\hline \multicolumn{7}{c}{ Model } & \multicolumn{2}{c}{$\mathbf{k = 2 7 , 2 5}$ MN } & \multicolumn{2}{c}{$\mathbf{k = 5 4 , 5} \mathbf{M N}$} & \multicolumn{2}{c}{$\mathbf{k = 8 1 , 7 5} \mathbf{M N}$} & \multicolumn{2}{c}{$\mathbf{k = 1 0 9} \mathbf{M N}$} \\
\cline { 2 - 10 } & $\begin{array}{c}\text { Maximum } \\
(\mathbf{m m})\end{array}$ & $\begin{array}{c}\text { Minimum } \\
(\mathbf{m m})\end{array}$ & $\begin{array}{c}\text { Maximum } \\
(\mathbf{m m})\end{array}$ & $\begin{array}{c}\text { Minimum } \\
(\mathbf{m m})\end{array}$ & $\begin{array}{c}\text { Maximum } \\
(\mathbf{m m})\end{array}$ & $\begin{array}{c}\text { Minimum } \\
(\mathbf{m m})\end{array}$ & $\begin{array}{c}\text { Maximum } \\
(\mathbf{m m})\end{array}$ & $\begin{array}{c}\text { Minimum } \\
(\mathbf{m m})\end{array}$ \\
\hline $\begin{array}{c}\text { Fase } \\
\text { Positif }\end{array}$ & 0.0115731 & $2.94 \mathrm{E}-19$ & 0.0113301 & $1.23 \mathrm{E}-18$ & 0.0110927 & $1.021 \mathrm{E}-21$ & 0.0108667 & $7.3 \mathrm{E}-19$ \\
\hline $\begin{array}{c}\text { Fase } \\
\text { Negatif }\end{array}$ & 0.0614331 & 0.054602 & 0.0605589 & 0.0534912 & 0.0597222 & 0.0524525 & 0.0589088 & 0.0514593 \\
\hline $\begin{array}{c}\text { Getaran } \\
\text { Bebas }\end{array}$ & 0.616336 & 0.437467 & 0.5932588 & 0.399146 & 0.5717294 & 0.3318769 & 0.5521356 & 0.284375 \\
\hline
\end{tabular}

Tabel 4. Nilai Lendutan dengan beban di tengah bentang untuk tebal pelat $230 \mathrm{~mm}$

\begin{tabular}{cccccccccc}
\hline \multicolumn{7}{c}{ Lendutan Absolut, Beban di Tengah Bentang } \\
\hline \multirow{2}{*}{ Model } & \multicolumn{2}{c}{$\mathbf{k}=\mathbf{2 7 , 2 5} \mathbf{M N}$} & \multicolumn{2}{c}{$\mathbf{k = 5 4 , 5} \mathbf{M N}$} & \multicolumn{2}{c}{$\mathbf{k = 8 1 , 7 5} \mathbf{M N}$} & \multicolumn{2}{c}{$\mathbf{k = 1 0 9} \mathbf{M N}$} \\
\cline { 2 - 9 } & $\begin{array}{c}\text { Maximum } \\
(\mathbf{m m})\end{array}$ & $\begin{array}{c}\text { Minimum } \\
(\mathbf{m m})\end{array}$ & $\begin{array}{c}\text { Maximum } \\
(\mathbf{m m})\end{array}$ & $\begin{array}{c}\text { Minimum } \\
(\mathbf{m m})\end{array}$ & $\begin{array}{c}\text { Maximum } \\
(\mathbf{m m})\end{array}$ & $\begin{array}{c}\text { Minimum } \\
(\mathbf{m m})\end{array}$ & $\begin{array}{c}\text { Maximum } \\
(\mathbf{m m})\end{array}$ & $\begin{array}{c}\text { Minimum } \\
(\mathbf{m m})\end{array}$ \\
\hline $\begin{array}{c}\text { Fase } \\
\text { Positif }\end{array}$ & 0.0152796 & $6.26 \mathrm{E}-23$ & 0.0149333 & $5.157 \mathrm{E}-21$ & 0.0145959 & $7.454 \mathrm{E}-19$ & 0.0142664 & $7.454 \mathrm{E}-19$ \\
\hline $\begin{array}{c}\text { Fase } \\
\text { Negatif }\end{array}$ & 0.0950348 & 0.092249 & 0.0932362 & 0.0898259 & 0.0915559 & 0.0875917 & 0.0899569 & 0.0854955 \\
\hline $\begin{array}{c}\text { Getaran } \\
\text { Bebas }\end{array}$ & 1.7879356 & 1.373641 & 1.7225966 & 1.187019 & 1.6636586 & 1.1231785 & 1.6084851 & 1.048066 \\
\hline
\end{tabular}

Setelah disajikan tabel lendutan absolut pada masing-masing posisi beban, terlihat bahwa semakin dekat beban ke tengah bentang, semakin besar nilai lendutan absolut maksimum. Selain itu, utuk semua model dan semua posisi beban, lendutan absolut maksimum terjadi pada fase free vibration. Lendutan absolut maksimum sebesar $1,788 \mathrm{~mm}$ terjadi pada model untuk variasi kasus dengan nilai kekakuan lapisan tanah pendukung $\mathrm{k}=27,25 \mathrm{MN} / \mathrm{m}$ dengan posisi beban di tengah bentang pada pelat tebal $230 \mathrm{~mm}$. Pengurangan lendutan terjadi apabila nilai kekakuan lapisan pendukung semakin besar. Presentase pengurangan terhadap lendutan pelat pada variasi pelat $230 \mathrm{~mm}$ dengan nilai $\mathrm{k}=54,5 \mathrm{MN}, \mathrm{k}=81,75 \mathrm{MN}$, dan $\mathrm{k}=109 \mathrm{MN}$ berturut-turut adalah sebesar 3,65\%, 6,95\%, dan $10,04 \%$.

Sebagai perbandingan dilakukan presentase pengurangan lendutan yang terjadi apabila posisi beban ledakan ditinjau pada model dengan variasi kasus pelat $250 \mathrm{~mm}$. Lendutan absolut maksimum sebesar 0,616 mm terjadi pada model untuk variasi kasus dengan nilai kekakuan lapisan tanah pendukung $\mathrm{k}=27,25 \mathrm{MN} / \mathrm{m}$. Presentase pengurangan lendutan apabila tebal pelat dinaikkan menjadi $20 \mathrm{~mm}$ adalah sebesar $65,55 \%$. Adapun presentase pengurangan lendutan pelat pada variasi tebal pelat $250 \mathrm{~mm}$ dengan nilai $\mathrm{k}=54,5 \mathrm{MN}, \mathrm{k}=81,75 \mathrm{MN}$, dan $\mathrm{k}=109 \mathrm{MN}$ berturutturut adalah sebesar $3,74 \%, 7,24 \%$, dan $10,42 \%$. Hal ini menunjukkan bahwa pengaruh ketebalan pelat jauh lebih berpengaruh terhadap nilai lendutan dibandingkan menambahkan nilai kekakuan lapisan tanah pendukung.

\section{Lendutan Maksimum Absolut}

Salah satu asumsi mendasar yang digunakan dalam prosedur penurunan persamaan gerak pelat adalah bahwa lendutan yang terjadi adalah small deflection. Asumsi ini sangat berpengaruh dalam 
menyatakan hubungan momen-curvature dengan lendutan yang terjadi. Nilai lendutan yang diperoleh dari hasil analisis perlu dievaluasi ulang terhadap syarat ini untuk memvalidasi nilai yang diperoleh dari analisis. Nilai lendutan pelat dapat dinyatakan termasuk small deflection atau memenuhi syarat apabila yang terjadi tidak melebihi sepersepuluh bentang pelat.

Lendutan maksimum absolut untuk semua model pelat dengan semua posisi beban adalah 1,788 $\mathrm{mm}$ sedangkan lendutan izin untuk masuk kategori small deflection adalah:

$$
\delta_{a l l}=\frac{h}{10}=\frac{230}{10}=23 \mathrm{~mm}
$$

Lendutan maksimum absolut jauh dari batas lendutan izin $(1,788 \mathrm{~mm}$ « $23 \mathrm{~mm})$ sehingga semua analisis dapat dikatakan valid.

\section{Gaya - Gaya Dalam Pelat}

Gaya-gaya dalam berupa momen dan gaya geser dapat dihitung sesuai dengan teori lendutan kecil Kirchoff sebagai berikut:

Momen $\mathrm{m}_{\mathrm{x}}=-D_{x}\left(\frac{\partial^{2} w}{\partial x^{2}}+v_{y} \frac{\partial^{2} w}{\partial y^{2}}\right)$

Momen $\mathrm{m}_{\mathrm{y}}=-D_{y}\left(\frac{\partial^{2} w}{\partial y^{2}}+v_{y} \frac{\partial^{2} w}{\partial x^{2}}\right)$

Gaya Geser $\mathrm{q}_{\mathrm{x}}=-D_{x}\left(\frac{\partial^{3} w}{\partial x^{3}}+\left(\frac{2\left(1-\sqrt{v_{x}-v_{y}}\right) \sqrt{D_{x} D_{y}}}{D_{x}}+v_{y}\right) \frac{\partial^{3} w}{\partial x \partial y^{2}}\right)$

Gaya Geser $\mathrm{q}_{\mathrm{y}}=-D_{y}\left(\frac{\partial^{3} w}{\partial y^{3}}+\left(\frac{2\left(1-\sqrt{v_{x}-v_{y}}\right) \sqrt{D_{x} D_{y}}}{D_{y}}+v_{y}\right) \frac{\partial^{3} w}{\partial x^{2} \partial y}\right)$

Momen lentur arah $\mathrm{x}$ dan $\mathrm{y}$ merupakan turunan kedua dari fungsi lendutan $w(x, y, t)$. Selain itu, defleksi fungsi lendutan $w(x, y, t)$ bila diturunkan tiga kali maka akan diperoleh gaya geser pada sumbu $x$ dan $y$. Parameter analisis ini meletakkan momen terbesar terletak pada tengah bentang dimana $\mathrm{x}_{(0)}=\frac{a}{2}$ dan $\mathrm{y}_{(0)}=\frac{b}{2}$. Nilai momen lentur pelat arah $x$ dan arah $y$ untuk studi kasus dengan beban di tengah bentang atau pusat pelat $\left(\mathrm{x}_{(0)}=\frac{a}{2}\right.$ dan $\left.\mathrm{y}_{(0)}=\frac{b}{2}\right)$ pada interval waktu selama fase free vibration $(0,0054<\mathrm{t} \leq 0,25 \mathrm{~s})$ baik untuk tebal pelat $230 \mathrm{~mm}$ maupun tebal pelat $250 \mathrm{~mm}$, dimana pada fase tersebut momen maksimum terjadi. Nilai momen tersebut dapat dilihat pada Tabel 5 dan Tabel 6 sebagai berikut:

Tabel 5. Nilai Momen Lentur dan Gaya Geser pada Studi Kasus $\mathrm{h}_{\text {pelat }}=250 \mathrm{~mm}$

\begin{tabular}{cccccc}
\hline & \multirow{2}{*}{ Kasus } & \multicolumn{1}{c}{$1 \mathrm{~A}$} & \multicolumn{1}{c}{$1 \mathrm{C}$} & $1 \mathrm{D}$ \\
\cline { 3 - 6 } Momen & & \multicolumn{2}{c}{$\mathrm{x}_{0}=\mathrm{a} / 2 ; \mathrm{y}_{0}=\mathrm{b} / 2 ; \mathrm{t}=0,25 \mathrm{~m}$} \\
\hline Momen X & $\mathrm{k}=27.25 \mathrm{MN}$ & $\mathrm{k}=54.5 \mathrm{MN}$ & $\mathrm{k}=81.75 \mathrm{MN}$ & $\mathrm{k}=109 \mathrm{MN}$ \\
\hline Mx & {$[\mathrm{N} . \mathrm{m}]$ Max } & 20816.8 & 19409.4 & 18440.2 & 17782.1 \\
\hline Momen Y & {$[\mathrm{N} . \mathrm{m}]$ Min } & -15704.9 & -16853.1 & -17848.9 & -18705.9 \\
\hline My & {$[\mathrm{N} . \mathrm{m}]$ Max } & 58145.1 & 54566.6 & 51661.2 & 49237.5 \\
\hline Geser X & {$[\mathrm{N} . \mathrm{m}]$ Min } & -34641.8 & -35871.9 & -36857.3 & -37620.6 \\
\hline Qx & {$[\mathrm{N}]$ Max } & 91895.44 & 89398.92 & 87018.55 & 84732.87 \\
\hline
\end{tabular}


Tabel 6. Nilai Momen Lentur dan Gaya Geser pada Studi Kasus $\mathrm{h}_{\text {pelat }}=230 \mathrm{~mm}$

\begin{tabular}{cccccc} 
& \multirow{2}{*}{ Kasus } & $1 \mathrm{~A}$ & $1 \mathrm{~B}$ & $1 \mathrm{C}$ & $1 \mathrm{D}$ \\
\cline { 3 - 6 } & & \multicolumn{4}{c}{$\mathrm{x}_{0}=\mathrm{a} / 2 ; \mathrm{y}_{0}=\mathrm{b} / 2 ; \mathrm{t}=0,25 \mathrm{~m}$} \\
\hline Momen X & {$[\mathrm{N} . \mathrm{m}]$ Max } & 36100.8 & 34590.5 & 33170.3 & 31822.9 \\
\hline Mx & {$[\mathrm{N} . \mathrm{m}]$ Min } & -29557.0 & -33777.5 & -36464.7 & -37860.9 \\
\hline Momen $\mathrm{Y}$ & {$[\mathrm{N} . \mathrm{m}]$ Max } & 58291.9 & 54580.2 & 51120.9 & 47881.9 \\
\hline My & {$[\mathrm{N} . \mathrm{m}]$ Min } & -69889.0 & -77039.9 & -81690.7 & -84229.1 \\
\hline Geser X & {$[\mathrm{N}]$ Max } & 102203.38 & 99208.66 & 96356.92 & 93651.78 \\
\hline Qx & {$[\mathrm{N}]$ Min } & -143666.35 & -138276.25 & -133237.20 & -128483.81 \\
\hline
\end{tabular}

Berdasarkan Tabel 5 dan Tabel 6, dapat disimpulkan bahwa momen lentur arah x dan arah y menunjukkan perilaku yang sama dengan lendutan, momen lentur semakin kecil apabila makin besar nilai kekakuan lapisan tanah pendukung $k$, dan momen lentur semakin besar apabila tebal pelat semakin kecil. Pada kasus tebal pelat $\mathrm{h}=250 \mathrm{~mm}$, perhitungan momen lentur arah $\mathrm{x}$, kekakuan lapisan tanah pendukung $\mathrm{k}=27,25 \mathrm{MN}$ adalah 20816,8 Nm. Kekakuan lapisan tanah pendukung $\mathrm{k}=54,5 \mathrm{MN}$ mengurangi momen lentur sebesar 6,76\%. Kekakuan lapisan tanah pendukung $\mathrm{k}=81,75 \mathrm{MN}$ mengurangi momen lentur sebesar 11,42\%. Kekakuan lapisan tanah pendukung $\mathrm{k}=109 \mathrm{MN}$ mengurangi momen lentur sebesar 14,58\%.

Pada kasus tebal pelat $\mathrm{h}=230 \mathrm{~mm}$, perhitungan momen lentur arah $\mathrm{x}$, kekakuan lapisan tanah pendukung $\mathrm{k}=27,25 \mathrm{MN}$ adalah $36100,8 \mathrm{Nm}$. Kekakuan lapisan tanah pendukung $\mathrm{k}=54,5 \mathrm{MN}$ mengurangi momen lentur sebesar 4,18\%. Kekakuan lapisan tanah pendukung $\mathrm{k}=81,75 \mathrm{MN}$ mengurangi momen lentur sebesar 8,12\%. Kekakuan lapisan tanah pendukung $\mathrm{k}=109 \mathrm{MN}$ mengurangi momen lentur sebesar $11,85 \%$.

Sebagai perbandingan dengan nilai kekakuan lapisan tanah pendukung $k$ yang sama, dengan nilai $k=27,25 \mathrm{MN}$, apabila ketebalan pelat divariasikan dari tebal pelat $230 \mathrm{~mm}$ menjadi $250 \mathrm{~mm}$, maka momen lentur arah x berkurang sebesar 42,34\%. Dari hasil tersebut dapat disimpulkan bahwa menambahkan tebal pelat jauh lebih efektif dibandingkan menambah kekakuan lapisan tanah pendukung.

Gambar 3 menunjukkan Grafik 3D momen lentur arah $\mathrm{x}$ dan y untuk setiap kasus pada $\mathrm{t}$ (detik) selama fase free vibration $(0,0054<\mathrm{t} \leq 0,25 \mathrm{~s})$. Dari gambar tersebut juga terlihat bahwa respons dinamik maksimum terjadi pada saat posisi beban berada di tengah pelat. 

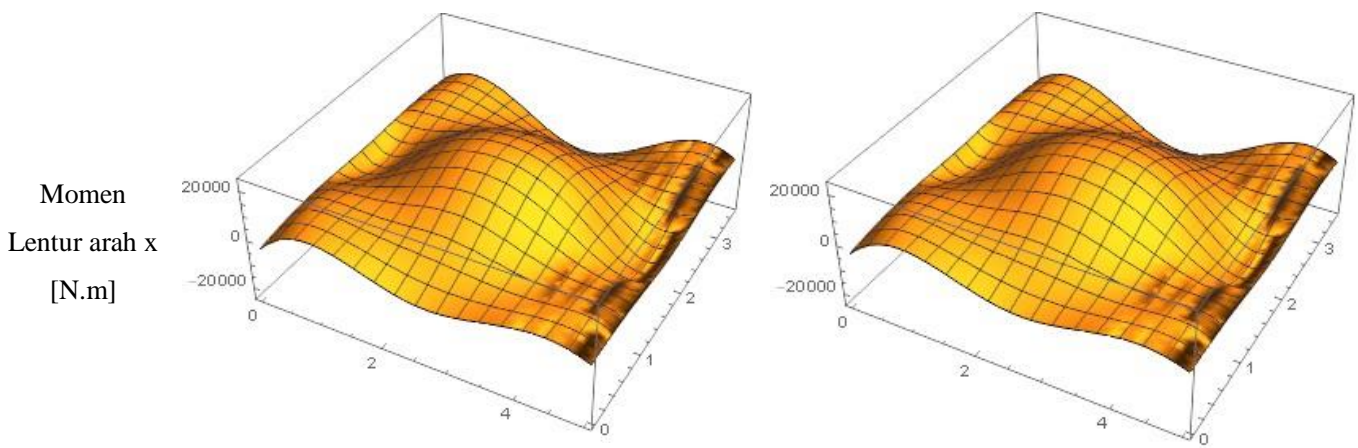

Kasus

$$
\mathrm{x}_{0}=4 / 8 \mathrm{a} ; \mathrm{k}=27,25 \mathrm{MN} ; \mathrm{h}=0,25 \mathrm{~m} ; \mathrm{t}=0,006 \mathrm{~s}
$$

$\mathrm{x}_{0}=4 / 8 \mathrm{a} ; \mathrm{k}=54,5 \mathrm{MN} ; \mathrm{h}=0,25 \mathrm{~m} ; \mathrm{t}=0,006 \mathrm{~s}$
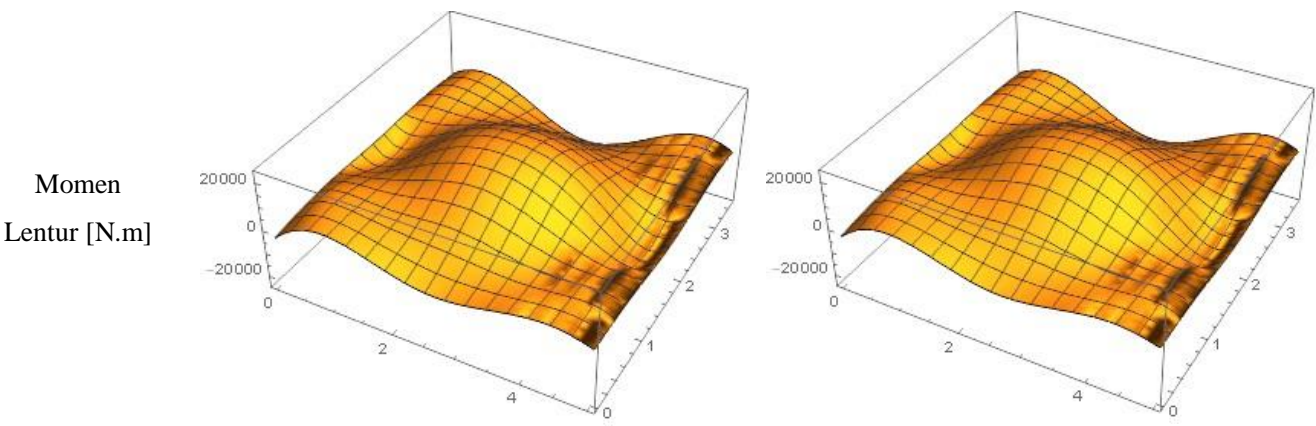

Kasus

$\mathrm{x}_{0}=4 / 8 \mathrm{a} ; \mathrm{k}=81,75 \mathrm{MN} ; \mathrm{h}=0,25 \mathrm{~m} ; \mathrm{t}=0,006 \mathrm{~s}$

$\mathrm{x}_{0}=4 / 8 \mathrm{a} ; \mathrm{k}=109 \mathrm{MN} ; \mathrm{h}=0,25 \mathrm{~m} ; \mathrm{t}=0,006 \mathrm{~s}$
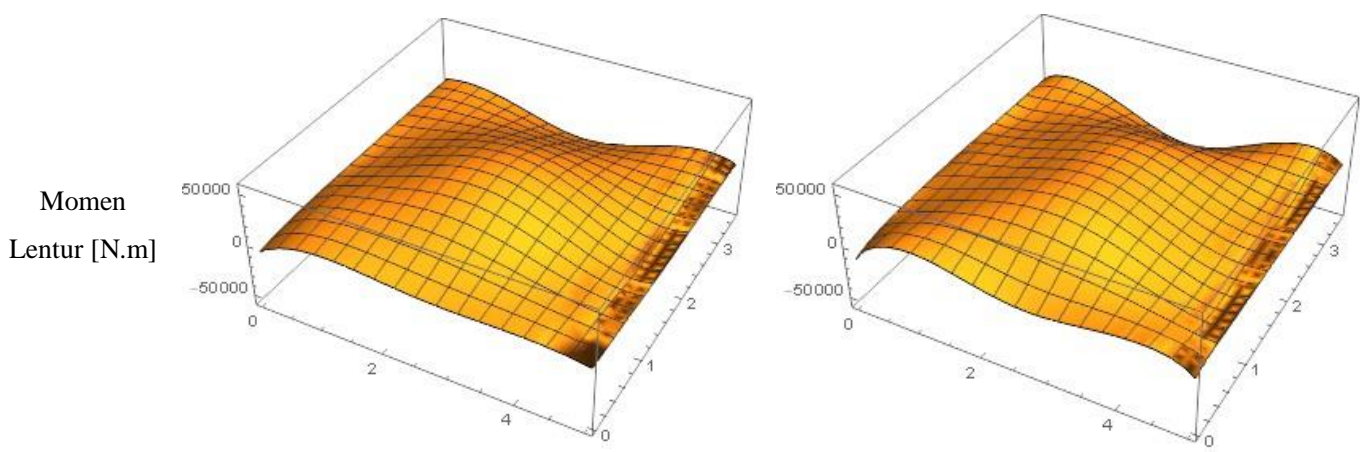

Kasus $\mathrm{x}_{0}=4 / 8 \mathrm{a} ; \mathrm{k}=27,25 \mathrm{MN} ; \mathrm{h}=0,23 \mathrm{~m} ; \mathrm{t}=0,0057 \mathrm{~s}$

$\mathrm{x}_{0}=4 / 8 \mathrm{a} ; \mathrm{k}=54,5 \mathrm{MN} ; \mathrm{h}=0,23 \mathrm{~m} ; \mathrm{t}=0,0057 \mathrm{~s}$

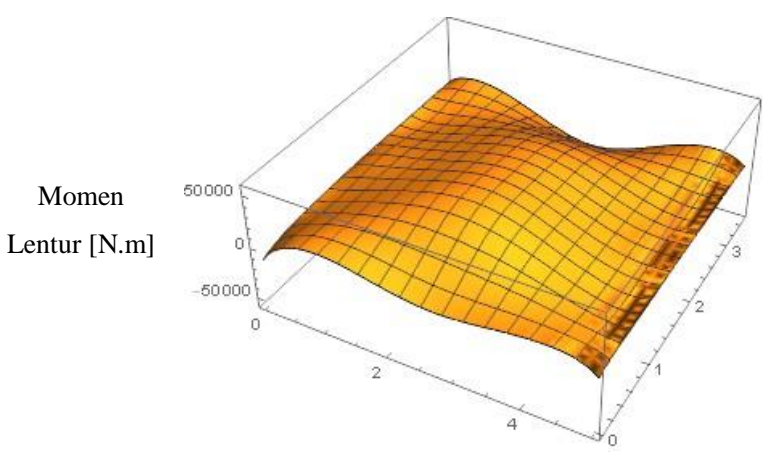

Kasus $\mathrm{x}_{0}=4 / 8 \mathrm{a} ; \mathrm{k}=81,75 \mathrm{MN} ; \mathrm{h}=0,23 \mathrm{~m} ; \mathrm{t}=0,0057 \mathrm{~s}$

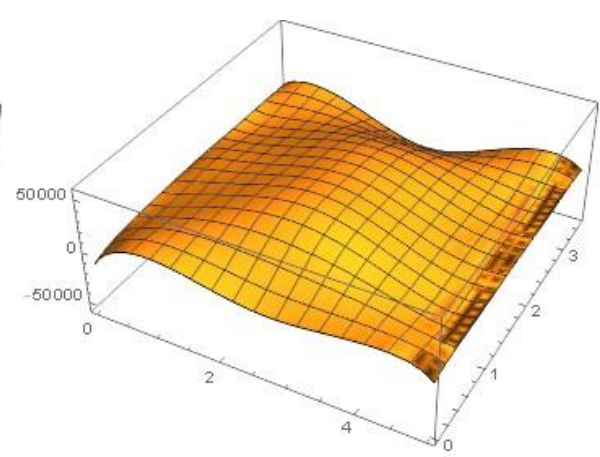

$\mathrm{x}_{0}=4 / 8 \mathrm{a} ; \mathrm{k}=109 \mathrm{MN} ; \mathrm{h}=0,23 \mathrm{~m} ; \mathrm{t}=0,0057 \mathrm{~s}$

Gambar 3. Grafik 3D Momen Lentur untuk Studi Kasus Beban di Tengah Bentang 
Gambar 4 dan Gambar 5 menunjukkan grafik gaya geser [N] terhadap $a$ [m] (jarak panjang pelat sejajar sumbu $x$ ) untuk studi kasus dimana posisi beban yang bekerja pada tengah bentang baik dengan tebal pelat $250 \mathrm{~mm}$ maupun tebal pelat $230 \mathrm{~mm}$. Dari gambar tersebut juga terlihat bahwa gaya geser maksimum terjadi berhimpitan dengan tepi pelat. Tepi pelat menunjukkan nilai geser tidak sama dengan nol (Geser $\neq 0)$ karena terdapat tumpuan dowel dan tie - bar pada tepi pelat. Pada Gambar 4 dan Gambar 5 juga menunjukkan gaya geser sama dengan nol terjadi pada tengah bentang, hal ini membuktikan bahwa terdapat kesesuaian hubungan dimana momen maksimum juga terjadi di tengah bentang.

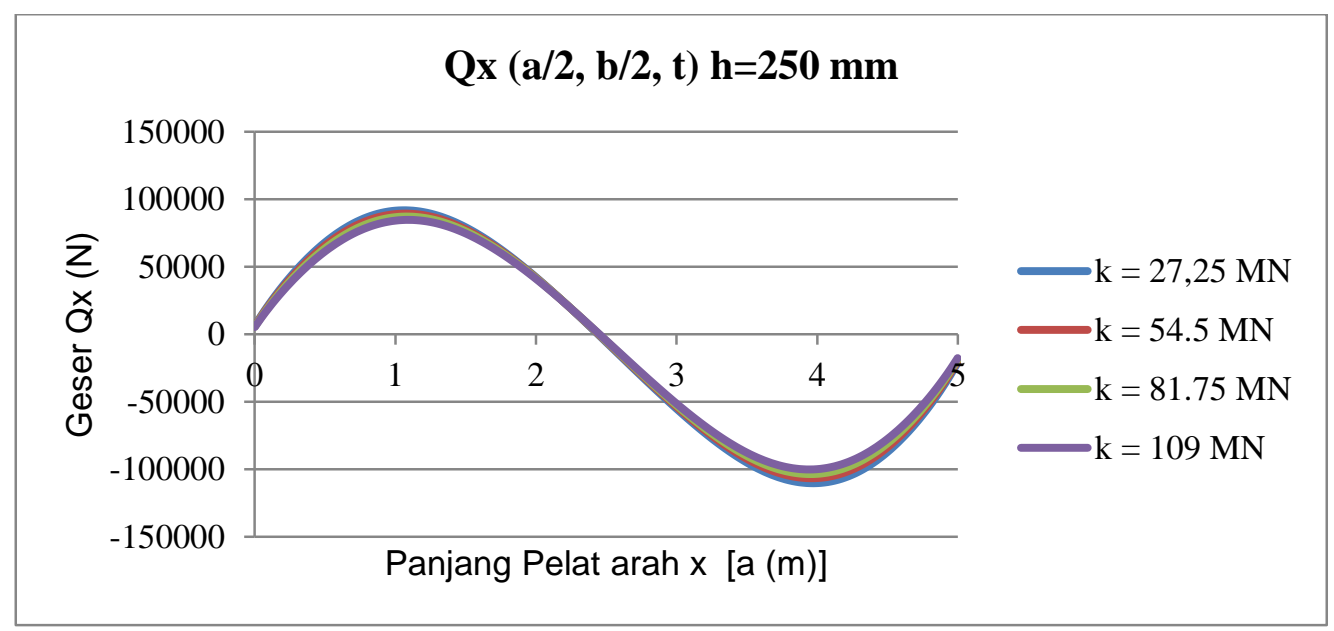

Gambar 4. Grafik Gaya Geser Pelat $\mathrm{h}=0,25 \mathrm{~m}$ untuk Beban di Tengah Bentang

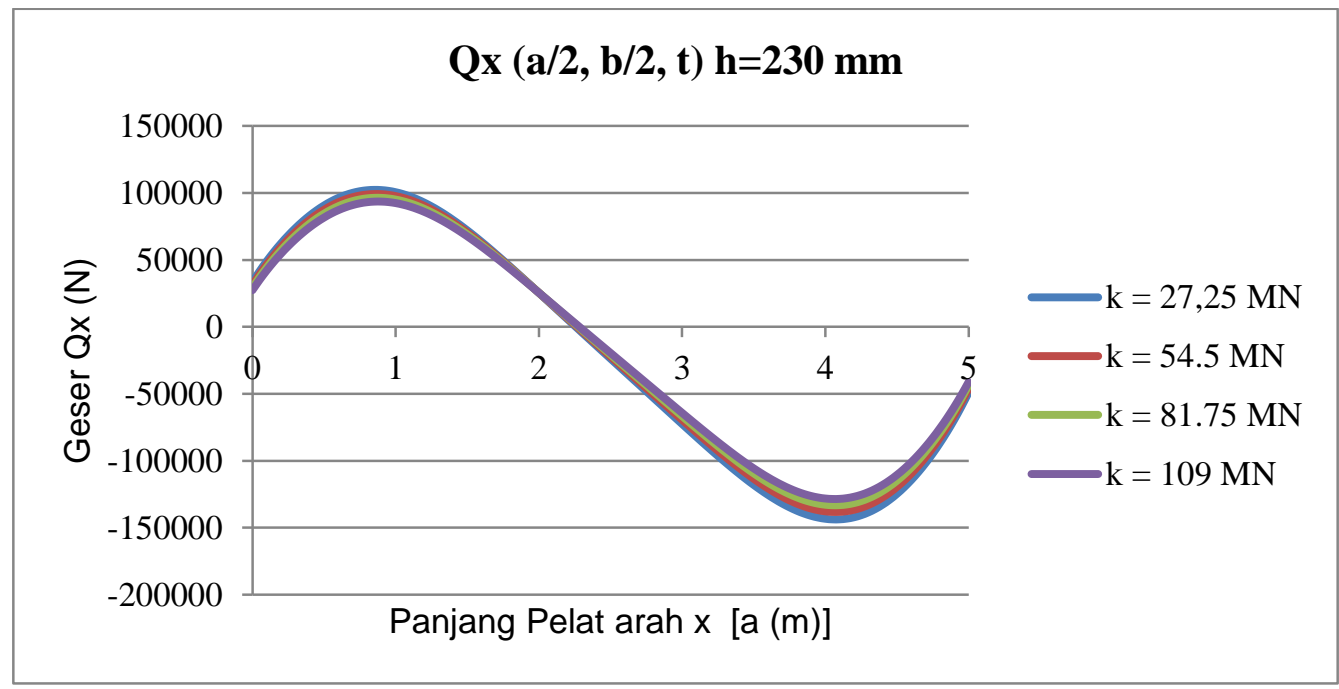

Gambar 5. Grafik Gaya Geser Pelat h =0,23 m untuk Beban di Tengah Bentang

\section{KESIMPULAN DAN SARAN}

\section{Kesimpulan}

Berdasarkan hasil analisis respons beberapa macam pelat terhadap beban ledakan setempat yang telah dikerjakan pada penelitian ini dapat diambil kesimpulan sebagai berikut:

a. Respons dinamik struktur terbesar terjadi pada fase free vibration, bukan pada fase positif maupun fase negatif. Hal ini dikarenakan adanya initial condition yang terjadi akibat akhir durasi pembebanan fase sebelumnya ternyata dapat menyebabkan nilai lendutan yang lebih 
besar dibandingkan lendutan selama durasi ledakan meskipun beban sudah tidak bekerja lagi pada pelat.

b. Penambahan kekakuan lapisan tanah pendukung memberi perubahan signifikan terhadap frekuensi alami pelat.

c. Penambahan ketebalan pelat dapat mengurangi nilai momen dan gaya geser pelat.

d. Penambahan nilai kekakuan lapisan tanah pendukung dapat mengurangi nilai momen dan gaya geser pelat.

e. Posisi beban berpengaruh signifikan pada respons dinamik pelat. Apabila semakin dekat posisi beban ledakan ke tumpuan, semakin kecil besaran lendutan yang terjadi.

f. Ketebalan pelat berpengaruh signifikan pada respons dinamik pelat.

g. Secara umum apabila ditinjau berdasarkan pengaruh paling singnifikan dalam mengurangi lendutan, ketebalan pelat adalah urutan pertama diikuti pengaruh posisi ledakan apabila terjadi makin ke tepi pelat, kemudian yang terakhir penambahan kekakuan lapisan tanah pendukung.

\section{Saran}

Penelitian untuk studi kasus tentang respons dinamik pelat ortotropik akibat beban ledakan pada permukaan tanah dikembangkan lebih lanjut dengan cara sebagai berikut:

a. Menambah pengaruh ketinggian beban ledakan dengan besaran beban ledakan yang akan digunakan pada saat melakukan analisa pelat.

b. Menambah pengaruh beban hidup dan pengaruh temperatur pada analisa untuk memperoleh hasil yang lebih riil terhadap respons dinamik pelat.

c. Menggunakan bentuk pelat yang lain seperti lingkaran atau poligon yang bukan persegi panjang.

d. Menggunakan eksperimen dengan model skala penuh di laboratorium atau sampel dari lapangan untuk mendapatkan hasil yang lebih realistis terhadap pelat.

\section{REFERENSI}

Alisjahbana, S.W (2002). Dynamic Response of Damped Orthotropic Plates on Kerr Foundation. Proceeding Structural, WCEE, Yokohama, Japan.

Alisjahbana, S.W (2003). Dynamic of Rigid Pavements. Proceeding EASEC 9, Bali.

Alisjahbana, S.W (2004). Penggunaan Modifiel Bolotin Method dalam Analisis Respons Dinamik

Pelat Orthotropik Persegi Panjang. Prosiding Seminar Sehari Purnabakti Prof. Ridwan

Suhud dan Prof. Wiratman W, 29 September 2004, Institut Teknologi Bandung, Bandung.

Alisjahbana, S.W (2006). Dynamic Response Rectangular Orthotropic Plate Supported by

Pasternak Foundation Subjected to Dynamic Load. First International Structural Specialty

Conference, Calgary, Alberta, Canada.

Alisjahbana, S.W. and Wiratman W. (2009). Dynamics Response of Stiffened Orthotropic Plate

Subjected to Blast Loading, in $8^{\text {th }}$ International Conference on Shock \& Impact Loads On

Structures, Adelaide, Australia.

Alisjahbana, S.W. (2011). Dinamika Struktur Pelat II, UB Press, ISBN 978-95879-4-8.

Alisjahbana, S.W. and Wiratman Wangsadinata (2015). Behavior of the Orthotropic Stiffened

Plate Subjected to Localized Blast Load, WiTness Press, Jakarta.

Alisjahbana, S.W. and Shota Kiryu (2019). Free Vibration of a Levy-type solution for plates based on two-variable refined plate theory by using SEM, in $3^{\text {rd }}$ Journal of Vibroengineering (JVE).

Alisjahbana, S.W. et. al (2020). Stress Analysis in Rigid Roadway Pavement with Discontinuities Subjected to Vehicle Movement, in $2^{\text {nd }}$ International Journal of Civil Engineering and Technology (IJCIET). 
Bolotin, V. V. (1960). The Edge Effect in The Oscillations of Elastic Shells. PMM Moscow, Russia, 24(5), pp. 831-843.

Chopra, A.K. (2012). Dynamics of Structures Theory and Applications to Earthquake Engineering, Prentice Hall, New Jersey.

Draganic, H. and Sigmund V. (2012). Blast Loading On Structures, J.J Strossmayer University of Osijek Faculty of Civil Engineering,Croatia.

Gibigaye, M (2018). Free Vibration Analysis of Dowelled Rectanglar Isotropic thin plate on a Modified Vlasov Soil Type by Using Disrete Singular Convolution Method. Cotonou, Benin.

Granstrom, S. A. (1956). Dynamic of Structures Theory and Applications to Earthquake Engineering. Prentice Hall, New Jersey.

Karlos, V. dan Solomos, G. (2013). Calculation of Blast Loads for Application to Structural Components, JRC Technical Reports, Italy.

Kerr, A. D (1964). A Study of New Foundation Model. Acta Mechanica, Springer-Verlag.

Kerr, A. D (1964). Elastic and Viscoelastic Foundation Models. Journal of Applied Mechanics Transactions, ASME, 31, pp 491-498.

Khadid, A. et al. (2007), Blast loaded stiffened plates, Journal of Engineering and Applied Sciences, Vol. 2(2) pp. 456-461.

King, Wilton W. (1974). Applications of Bolotin's Method to Vibrations of Plates. AIAA Journal, 12(3), pp. 399-401.

Pevzner, P. \& Weller, T. \& Berkovits, A. (2000). Further Modification of Bolotin Method in Vibration Analysis of Rectangular Plates. AIAA Journal, 38(9), pp. 1725-1729.

Rigby, et al (2014). The Negative Phase of the Blast Load, in International Journal of Protective Studies 5 (1)

Susler, et al (2012). The Nonlinear Dynamic Behaviour of Tapered Laminated Plates Subjected to Blast Loading. Shock and Vibration Volume 19 Number 6.

Szillard, R. (1974). Theories of Analysis of Plates : Classical and Numerical Methods. Prentice Hall, Inc, New Jersey.

Szillard, R. (2004). Theories and Applications of Plate Analysis: Classical, Numerical, and Engineering Methods. John Wiley \& Sons, Inc., Hoboken, New Jersey.

Timoshenko, S. (1951). Theory of Elasticity $2^{\text {nd }}$ Edition, McGraw-Hill Book Company, New York. Vijakumar, K. (1971). A New Method for Analysis of Flexural Vibration of Rectangular Orthotropic Plates, in Journal of the Aeronautical Society of India, India 
PERILAKU DINAMIK PELAT PERKERASAN KAKU JALAN

Anjas Budi Priono

RAYA AKIBAT BEBAN LEDAKAN SETEMPAT 